\title{
Strategic Planning and Management of High-Tech Developments and Innovative Technical Solutions
}

\author{
Sergey Novikov ${ }^{1}$, Elmira Amirova ${ }^{2}$, Elena Kosykh $^{3}$, Marina Chudinovskikh ${ }^{4} \&$ Olga Nikolaevskaya $^{5}$ \\ ${ }^{1}$ Institute of Engineering Economics and Humanities, Moscow Aviation Institute, Moscow, Russia \\ ${ }^{2}$ Economics and Information Technology Department, Kazan State Agricultural University, Kazan, Russia \\ ${ }^{3}$ Department of Theory and History of State and Law, Sterlitamak Branch of Bashkir State University, Sterlitamak, \\ Russia \\ ${ }^{4}$ Department of Public Law, Ural State University of Economics, Yekaterinburg, Russia \\ ${ }^{5}$ Department of Customs Administration, High School of Economics and Management, South Ural State University \\ (National Research University), Chelyabinsk, Russia
}

Correspondence: Sergey Novikov, Institute of Engineering Economics and Humanities, Moscow Aviation Institute, Volokolamskoe shosse, 4, building 5, 125993, Moscow, Russia. Tel: 7-343-257-9140. E-mail: ncsrm@mail.ru

Received: August 15, 2019

doi:10.5430/rwe.v10n3p309
Accepted: September 25, 2019

Online Published: December 15, 2019

\begin{abstract}
The innovation-oriented activity of enterprises is vital to the formation of competitive positions of the national economy on the world scene. Moreover, the importance of innovation is due to the complex modern economic conditions. Because of the sanctions from developed countries, it is necessary to increase production activities within the country in order to meet domestic demand, as well as to improve cooperation with the countries of the Eurasian Economic Union and Southeast Asia. The study focuses on strategic planning and management of high-tech developments and innovative technical solutions. The authors predicted the financing of science in Russia until 2030. The paper uses comparative analysis, systematization, induction, and deduction. Russia has developed a positive trend in financing the R\&D sphere until 2030, which will improve its position in the global competitiveness rating. These findings can be used by managers of enterprises with innovation activities, by authorities regulating innovation activities in Russia, and by specialists in the field of innovation.
\end{abstract}

Keywords: research and development (R\&D), innovation, financing, planning, science, engineering

\section{Introduction}

The entire modern politics at the global level, including in the field of science, technology, and innovation, is based on forecasting and strategic planning, monitoring and analysis of data, which is an international universal trend.

Grilli et al. (2018) examine the promising research areas for assessing the effectiveness and impact of financing innovation. The articles by Kapetaniou (2018), Lanahan and Feldman (2015), van Rijnsoevera et al. (2015), Padilla-Pérez and Gaudin (2014), Liu et al. (2011) analyze national innovation systems, which focus on improving the efficiency of innovation activities by expanding the availability of financial instruments and their accessibility to entrepreneurs. Bryan and Lemus (2017), Borrás and Edquist (2013), Nill and Kemp (2009) in their works examine various types of innovation policy tools.

Klochikhin (2012) believes that over the past twenty years, Russia has struggled to become an effective market economy. Innovation and technological developments are one of the best ways to achieve impressive results. This article examines new approaches to financing innovation.

Moiseev (2018) described the key sources of R\&D funding in Russia, reviewed their effectiveness in practice, identified several barriers to the effectiveness of financial support for $R \& D$ in the field of nanotechnology, and suggested means to improve the efficiency of R\&D funding in this area.

Mukaidekh and Mukaidekh (2018), and Zakharova (2018) conduct a comparative analysis of the level of expenses for the financing of science in Russia and the top ten foreign countries in terms of R\&D funding. 
The concept of sustainable development of the United Nations involves the development of science, technology, and innovation, which implies increased opportunities in information and communication technology, scientific-technical and innovation potential in terms of national development planning. At the same time, the international community calls for using strategic planning and forecasting as a platform for discussing issues in the field of science and technology policy among all interested parties, including the representatives of public authorities, the scientific community, business, and civil society. That is why, the goal of the research is to indicate strategic planning and management tools for high-tech developments and innovative technical solutions.

\section{Method}

The methodical research apparatus includes general scientific and economic methods. The authors used a synthesis of abstract-theoretical analysis, system, factor, and structural-functional analysis, the logical approach, statistical methods, simulation, the situational and quantitative approaches. They also applied customized methodical tools of economic and mathematical modeling.

Various statistical materials, reporting data of the executive authorities, monographs and publications, Internet resources of the leading research centers of Russia served as the information and regulatory base for this research. The authors also used the results of their own research, as well as the decrees of the President of Russia, resolutions of the Federal Government, other regulatory legal and methodological documents of legislative and executive authorities of all levels of governance of the Russian Federation, including program documents.

\section{Results}

To date, the Federal Law "On Strategic Planning in the Russian Federation" of June 28, 2014, No. 172-FZ (2014) exclusively regulates all issues of strategic planning in the field of scientific and scientific-technical activities in the Russian Federation. This law involves the development of the two main primary planning documents for a long-term period in this sphere: the forecast of scientific and technological development of the Russian Federation and the strategy of scientific and technological development of the Russian Federation.

On January 3, 2014, the Government of Russia approved the forecast of the Russian Federation for the period until 2030. To activate innovation activity in Russia, the government introduced a system of program-targeted management. The major target programs for the development of science and technology in Russia are presented below.

1. Federal Targeted Program: "R\&D for Priority Areas of the Development of the S\&T Complex of Russia" for the 2014-2020" (2013). The projected funding of the Program in 2014-2020 will amount to 179.84 billion rubles.

2. The state program of the Russian Federation "Development of Science and Technologies" for 2013-2020" (2014). The amount of financial support for this program in 2013-2020 will amount to 1294.99 billion rubles.

3. The state program of the Russian Federation "Development of Industry and Increasing Its Competitiveness" (2014). The amount of financing for this program is 1290.46 billion rubles.

Based on the analysis of these programs, the authors predicted the financing of science in Russia until 2030 (Figure 1).

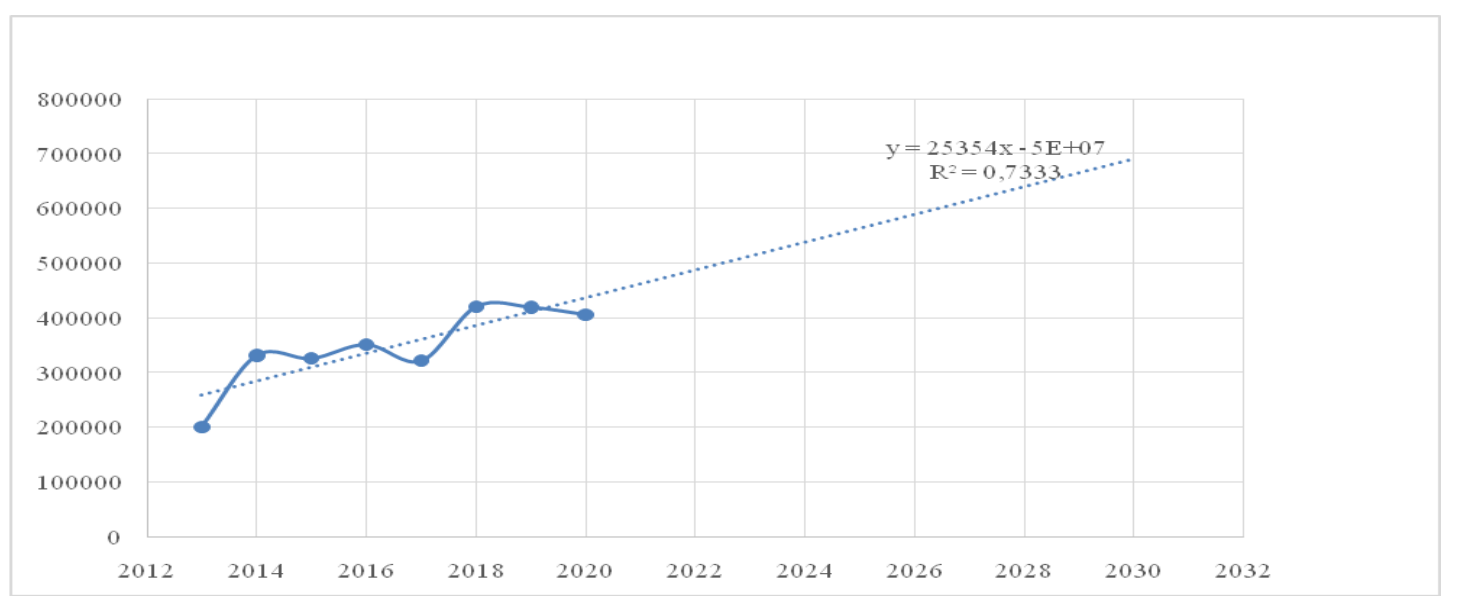

Figure 1. The forecast of R\&D financing in Russia until 2030, compiled by the authors 
Figure 1 shows a positive trend of R\&D funding in the Russian Federation. Article 18.1 of the Federal Law "On Strategic Planning in the Russian Federation" provides that the strategy of scientific and technological development of the Russian Federation is developed for a long-term period in order to provide scientific support for implementation of the strategy of socio-economic development of the Russian Federation, the strategy of national security of the Russian Federation under the strategic forecast of the Russian Federation, the forecast of the socio-economic development of the Russian Federation for the long term, the forecast of scientific-technological development of the Russian Federation and is approved by the President of Russia.

The strategy of scientific and technological development of the Russian Federation provides a basis for the adoption of sectoral strategic planning documents in the field of scientific and technological development, developed in the framework of goal-setting; state programs of the Russian Federation; state programs of constituent entities of the Russian Federation; as well as planning and program-targeted documents of state corporations and joint stock companies with state participation.

Furthermore, the Decree of the President of the Russian Federation of December 1, 2016, No. 642, has approved the Strategy for Scientific and Technological Development of the Russian Federation. Considering the federal status of the two main strategic planning documents in the field of science and innovations consolidated by the decree mentioned above, the new law on scientific, technical and innovation activity developed based on the Concept (The Ministry of Education and Science of the Russian Federation, 2018) should reflect the features of strategic planning and forecasting in the scientific and scientific-technical field. Moreover, the new law should include the definition of "big challenges" facing the Russian Federation and setting priorities for the scientific and technological development of the Russian Federation among the objectives of strategic planning in this sphere.

The priorities of scientific and technological development of the Russian Federation must be indicated in the strategy of scientific and technological development of the Russian Federation. Those should provide the basis for the register of relevant technologies approved by the Russian Government and anticipated from implementing the strategy of scientific and technological development of the Russian Federation.

It is the law on science to consolidate a special role of the Russian Academy of Sciences (RAS) in strategic planning of scientific, scientific-technical and innovative activities.

The introduction of the basic concepts and institutions of strategic planning and forecasting in the field of scientific, scientific-technical and innovation activities into the law on scientific, scientific-technical and innovation activities fully corresponds to the internationally recognized importance of the role of strategic planning and forecasting.

It is also necessary to consolidate the legal status of the National Technology Initiative (hereinafter the NTI) at the regulatory level. The Decree of the Government of the Russian Federation of April 18, 2016, No. 317 "On the Implementation of the National Technology Initiative" has adopted several regulatory documents. Those include the Rules for the Development and Implementation of Action Plans ("road maps") of NTI; the Regulation on Development, Selection, Implementation, and Monitoring of NTI Projects; the Rules for Granting Subsidies from the Federal Budget for Projects Implemented in the Framework of NTI Action Plans ("road maps"). However, this act does not contain a definition of the NTI. Therefore, it is rather difficult to integrate it into the existing system of strategic planning.

Increasing the effectiveness of scientific research through the use of the obtained results of scientific and scientific-technical activities requires the inclusion of a set of mechanisms (tools) in the legislation on scientific, scientific-technical and innovative activities, aimed at:

1) improving the monitoring of research and evaluating its effectiveness;

2) improving access to the reporting system on the results of scientific, and scientific-technical activities, funded under the state budget;

3) promoting the use of the results of scientific, and scientific-technical activities funded under the state budget.

The current legislation on scientific and scientific-technical activities does not provide a universal mechanism for monitoring and managing the effectiveness of scientific activities; the regulation is fragmentary.

The Decree of the Government of the Russian Federation No. 312 "On Evaluation and Monitoring of the Performance of Scientific Organizations Performing Research, Development and Technological Works for Civilian Purposes" of April 8, 2009 approved the relevant Rules for Evaluation and Monitoring. Those establish the procedure for assessment and annual monitoring of the performance of scientific organizations subordinated to federal executive bodies that perform research and development and technological works for civilian purposes. 
According to these rules, the main purpose of monitoring the performance of scientific organizations is to "ensure an objective departmental assessment of the performance of scientific organizations, as well as to unite scientific organizations in comparable reference groups, including on the field and (or) branch of science, organizational-legal form, the ratio of basic research and applied research, development and experimental research, membership in strategic enterprises and strategic joint-stock companies".

These rules provide that according to the results of its performance evaluation, a scientific organization can be assigned to one of the following categories:

1 - the leading scientific organizations;

2 - stable scientific organizations that demonstrate satisfactory performance;

3 - scientific organizations that have ceased to carry out scientific activities as their main activity and have lost their development prospects.

Not only restrictions on the list of objects for monitoring and evaluation, but also the lack of system requirements for evaluating the effectiveness of scientific and scientific-technical projects financed from the state budget (regardless of the jurisdiction of scientific organizations and their forms of ownership) constitute a serious shortcoming of the existing regulation of monitoring and evaluation procedures in the field of science.

Without monitoring the results of scientific, technical and innovation activity, it is impossible to identify the weaknesses of the regulatory system and take effective measures to strengthen its weaker elements at the political and regulatory level and make necessary adjustments to the strategic planning documents.

\section{Discussion}

The Federal Law No. 127-FZ "On State Science and Technology Policy" of August 23, 1996 does not even mention monitoring in relevant areas of activity, which does not allow for systematic and high-quality evaluation of the implementation of adopted strategic planning documents in the sphere of science and innovation.

Accordingly, the new law on science should fill the existing gap by defining the procedure for state monitoring in the field of science and innovation.

Data of state information systems in the field of science should be used in full when monitoring science and innovation. Numerous international documents emphasize the particular importance of these data when describing such an important trend in the regulation of scientific and scientific-technical activity as the creation of the "Open Science" system. Creating a monitoring system without using state information systems solely by imposing additional information duties on the subjects of scientific and scientific-technical activity will only become an additional burden.

As for the improvement of reporting systems on the results of scientific and scientific-technical activities funded under the state budget, it is necessary to note some serious weaknesses in their regulation.

Russian legislation virtually has no requirements for the content and procedure for reporting the results of research and development activity. There is only an interstate standard with a rather detailed description of the requirements (GOST 7.32-2001, 2001). According to paragraph 3.1 of this standard, the report on R\&D activity is a scientific and technical document that contains systematized data on research work, describes the state of the scientific and technical problem, the process and (or) the results of the scientific research. However, this definition is not a regulation and is applied voluntarily. All requirements for R\&D reports including their content, composition, submission and delivery procedure, the level and categories of access to reports, are set either at the level of orders released by state customers (when conducting $\mathrm{R} \& \mathrm{D}$ within the state order), or at the level of grantmakers documents (when performing R\&D through grants from funds supporting scientific and technical activities). Therefore, it is necessary to solve the systemic problem of regulating the status of $R \& D$ reporting by creating a new science law. Another problem is the impossibility of automatic opening access to R\&D reports (or its parts) to the public, as any $R \& D$ report is subject to copyright and access to it is possible only with the permission of right holders and under agreed conditions.

The results of scientific research in the civil area, that is, carried out at the expense of budget funds and at the same time not related to ensuring the defense and security of the state, should be available to an unlimited number of persons, since otherwise the efficiency of using budget funds for scientific research diminishes.

Therefore, it is necessary to define the procedure to access $R \& D$ reports at the regulatory level and designate the scope of third-party access rights: 
1) full access without the consent of the copyright owner;

2) partial access without the consent of the copyright holder;

3 ) access with the consent of the copyright holder and on terms agreed with the copyright holder.

The level of access should differ, first, depending on the type of research (fundamental, applied, exploratory), and secondly, on the use of $R \& D$ reports by the right holder (as a rule, in the field of civil $R \& D$, the right holder is the R\&D performer).

The promotion of the use of the results of scientific and scientific-technical activities should be carried out in two directions:

1) legislating the requirements for the use of $R \& D$ results and the consequences of neglecting this requirement;

2) changing the approach to the use of $R \& D$ results assigned to the performer.

The first direction was discussed in detail when making changes to the Civil Code of the Russian Federation in 2012-2013. However, the initiative remained underdeveloped.

To date, there is a regulatory framework to distribute the rights to the results of scientific and scientific-technical activities created by the state and municipal contracts. Let us consider it by the example of works of science, and more specifically, the report on R\&D - article 1298 of the Civil Code of the Russian Federation (1994).

\section{Conclusion}

The exclusive right to a work of science created under a state or municipal contract for state or municipal needs belongs to the performer who is the author or other person who fulfills the state or municipal contract, if the state or municipal contract does not stipulate that this right belongs to the Russian Federation, the subject of the Russian Federation or municipality, on behalf of which the state or municipal customer acts, or jointly to the performer and the Russian Federation, the performer and the subject of the Russian Federation or the performer and the municipality.

If the exclusive right to a work of science, literature or art created under a state or municipal contract for state or municipal needs does not belong to the Russian Federation or a subject of the Russian Federation or a municipal entity, the right holder at the request of the state or municipal customer must provide the person specified by him a simple (non-exclusive) grant license to use the corresponding work of science, literature or art for state or municipal needs.

Similar provisions can be found in Art. 1373, 1432, 1464, 1471 of the Civil Code. Chapter 38 of the Civil Code of the Russian Federation, which regulates the rights and obligations of a customer and a contractor under the R\&D contract, does not establish the obligation of a contractor under a state or municipal contract to use R\&D results.

Considering that these articles of the Civil Code refer only to the results of scientific and scientific-technical activities created under a state or municipal contract, which is a contract for performing R\&D, this means that the obligations of the copyright holder of $R \& D$ results created under the agreement on granting from state funds supporting scientific, scientific-technical and innovation activities or at the expense of state-assigned funds cannot be regulated even by amending the relevant articles of the Russian Civil Code.

The authors suggest that the law on science can and should establish the obligation of stakeholders in the field of science to use the results of scientific and scientific-technical activities created at the expense of budget funds or public funds. Moreover, it must define the "use of the results of scientific and scientific-technical activities" and establish consequences of failure to perform this obligation.

As for the second direction, considering the international experience, it is necessary to suggest the following models of encouraging the use of $\mathrm{R} \& \mathrm{D}$ results:

1) providing free access to the results of $R \& D$ created by educational and scientific organizations (such an obligation must be included in all contracts, state assignments, provided that the R\&D results were not used during the year);

2) providing performers with the rights to $R \& D$ results.

\section{References}

Borrás, S., \& Edquist, C. (2013). The choice of innovation policy instruments. Technological Forecasting and Social Change, 80(8), 1513-1522 https://doi.org/10.1016/j.techfore.2013.03.002

Bryan, K. A., \& Lemus, J. (2017). The direction of innovation. Journal of Economic Theory, 172, $247-272$ 
https://doi.org/10.1016/j.jet.2017.09.005

Civil Code of the Russian Federation. (1994, October 21) (latest revision). "Garant" legal information system. Retrieved from http://base.garant.ru/10164072/

Decree of the Government of the Russian Federation "Federal Targeted Programs: "R\&D for Priority Areas of the Development of the S\&T Complex of Russia" for the 2014-2020" of May 21, 2013, No. 426 (as amended and supplemented).

Decree of the Government of the Russian Federation "Forecast of Scientific and Technological Development of the Russian Federation for the Period up to 2030", adopted by the Government of the Russian Federation on January 3, 2014. Retrieved from http://static.government.ru/media/files/41d4b737638b91da2184.pdf

Decree of the Government of the Russian Federation "On Approval of the State Program of the Russian Federation "Development of Science and Technologies" for 2013-2020" of April 15, 2014, No. 301 (as amended and supplemented).

Decree of the Government of the Russian Federation "On Approval of the State Program of the Russian Federation "Development of Industry and Increasing Its Competitiveness" of April 15, 2014, №. 328.

Decree of the Government of the Russian Federation "On Evaluation and Monitoring of the Performance of Scientific Organizations Performing Research, Development and Technological Works for Civilian Purposes" of April 8, 2009, No. 312 (as amended and supplemented).

Decree of the President of the Russian Federation "On the Strategy of the Scientific and Technological Development of the Russian Federation" of January 12, 2016, No. 642 (latest revision).

Federal Law "On State Science and Technology Policy” of August 23, 1996, No. 127-FZ (latest revision).

Federal Law of the Russian Federation "On Strategic Planning in the Russian Federation" of June 28, 2014, No. 172-FZ (latest revision).

Grilli, L., Mazzucato, M., Meoli, M., \& Scellatod, G. (2018). Sowing the seeds of the future: Policies for financing tomorrow's innovations. Technological Forecasting \& Social Change, 127, 1-7.

Kapetaniou, C. (2018). Innovation policies of Cyprus during the global economic crisis: Aligning financial institutions with National Innovation System. Technological Forecasting \& Social Change, 133, 29-40 https://doi.org/10.1016/j.techfore.2018.02.019

Klochikhin, E. A. (2012). Russia's innovation policy: Stubborn path-dependencies and new approaches. Research Policy, 41(9), 1620-1630.

Lanahan, L., \& Feldman M.P. (2015). Multilevel innovation policy mix: A closer look at state policies thataugment the federal SBIR program. Research Policy, 44(7), 1387-1402 https://doi.org/10.1016/j.respol.2015.04.002

Liu, F. C., Simon, D. F., Sun, Y. T., \& Cao, C. (2011). China's innovation policies: Evolution, institutional structure, and trajectory. Research Policy, 40(7), 917-931 https://doi.org/10.1016/j.respol.2011.05.005

Moiseev, M. V. (2018). Cash Flow and R\&D performance indicators. Business and Society, 2, 16-28.

Mukaidekh, E. A., \& Mukaidekh, A. R. A. (2018). Problems and prospects for funding research in Russia based on foreign experience. Bulletin of the Educational Consortium of the Central Russian University. Economics and Management series, 11, 102-107.

Nill, J., \& Kemp, R. (2009). Evolutionary approaches for sustainable innovation policies: From niche to paradigm?. Research Policy, 38(4), 668-680 https://doi.org/10.1016/j.respol.2009.01.011

Padilla-Pérez, R., \& Gaudin, Y. (2014). Science, technology and innovation policies in small and developing economies: The case of Central America. Research Policy, 43(4), 749-759 https://doi.org/10.1016/j.respol.2013.10.011

The Ministry of Education and Science of the Russian Federation. (2018). The Draft Federal Law "On Scientific, Scientific-Technical and Innovation Activities" Retrieved "On http://www.ras.ru/FStorage/Download.aspx?id=b528ec83-ec28-476d-85ff-89975199d3e6

Van Rijnsoevera, F. J., van den Berg, J., Koch, J., \& Hekkert, M. P. (2015). Smart innovation policy: How network position and project composition affect the diversity of an emerging technology. Research Policy, 44(5), 1094-1107 https://doi.org/10.1016/j.respol.2014.12.004

Zakharova, E. A. (2018) Cross-country comparative analysis of R\&D financing in the structure of GDP. European Student Scientific Journal, 6, 111-119. 